\title{
Structure of the Chemical Denudation and Methods of Its Determination
}

Denmukhametov R.R. ${ }^{a}$

\author{
Sharifullin A.N. ${ }^{b}$ \\ ab Kazan Federal University, Institute of Management, Economics and Finance, Kazan, 420008, Russia
}

\section{Doi:10.5901/mjss.2015.v6n1s3p247}

\begin{abstract}
The intensity of chemical denudation is instituted by three miscellaneous groups of methods. The regularities of allocation of magnitude of chemical denudation till a drain of dissolved solids for natural zones and mountainous zones of a world are detected. The method of tablets determines magnitude of chemical denudation on natural zones, and also its intrabasin differentiation on relief elements and lithological rocks.
\end{abstract}

Keywords: chemical denudation, drain of dissolved solids, pattern of chemical denudation, method of tablets, denudational decrease, zonality of chemical denudation

\section{Introduction}

The quantitative assessment of magnitude of chemical denudation can be received by different methods, which one are aggregated by us in three groups: drain of dissolved solids (DDS); account of loss of a weight of standard samples of rocks (method of tablets); design methods. Each group of methods rests on a different host material, gives an estimation of chemical denudation with miscellaneous detail and mirrors the aspects of dissolution of rocks, their chemical transforming and consequent offset of products of a chemical weathering. Depending on features of an applied method pattern of chemical denudation variously can be deciphered, which one is understood as a set of the genetic constituents, their proportion among themselves and absolute values of each of them. For geoecological and geomorphological of the purposes, and also for understanding a genesis of the separate constituents of chemical denudation its separation on surface and underground, natural and anthropogenicly conditioned, denudation of dissolution and weathering is most important $[3,4,6,7,9-11]$.

\section{Method}

The DDS after separation denudational (litogenic) component allows rather precisely to evaluate chemical denudation both in dimensional, and in temporary aspects. The datas on this aspect of a solid discharge of the rivers are most suitable for structural partition of chemical denudation. The limitations, bound with usage of this method, are reduced to large dimensional (basin) to generalizing of magnitudes of denudation and to necessity of a very careful choice of methods of separation undenudational of a part of a DDS. Always it is necessary to allow for very irregular arranging of stations of hydrochemical observations and non-simultaneous period of observations.

The method of tablets which are built up in the experimental purposes in different conditions, allows extremely in detail to evaluate dimensional variability of chemical denudation, including inside a river basin and even on separate ground features [8]. This method well determines also discrepancies in dissolubility miscellaneous on lithologic to composition of rocks. The broad applying of a method is precluded by its large complexity.

The design methods are rather multiple and allow for the rather different factors which are capable to influence on magnitude of chemical denudation. Most widely they will be utillized for an estimation of extreme development of chemical denudation - karst. The greatest notoriety from these methods was received a so-called hydrometric method of Corbel [1, 2], which one use now will be utillized for accounts of intensity of karst denudation in regional studies. Though already for a long time most miscellaneous explorers resting on actual, instead of design material convincingly rotin an inaccuracy of theoretical assumptions of Corbel and their conflict with the substantial facts about progressing chemical denudation, specially about nature of its zonal variation. L.Jakucs [5] has described the Corbel's theoretical deductions as ".. one of most effective, but error doctrines of geomorphology". 


\section{Result}

We for an estimation of intensity of chemical denudation utilis separate methods of all three groups. They allow from different stands to determine an oilpainting of dimensional differentiation of an offset of a material in a dissolved aspect.

The method of application of structural partition of a DDS of for account of intensity of chemical denudation was designed at detailed analysis of this process on Roshydromet's materials of overseeings by an river's water and chemical drain in East of Russian plain. The datas are recently collected and the hydrochemical database on 1120 stations of observations disposed on all continents is created except for Antarctica.

The mathematic-statistical treating of this database has allowed to reveal zonal differentiation DDS in different natural zones of plains and altitude zones of mountains of the Earth. From all diversity of the factors, defining intensive chemical denudation, basic are an water drain and lithologic composition of basins's. Water drain is integrated reflex of climatic conditions and, in communal, is zonal.

All natural zones on plains can be determined on 5 groups on intensity of chemical denudation (D) (Table 1).

Table 1. The natural zones groups on intensity of chemical denudation

\begin{tabular}{llc}
\hline Groups of natural zones & Natural zones & $\begin{array}{c}\mathrm{D}, \\
\mathrm{t} / \mathrm{km}^{2} \text { year }^{-}\end{array}$ \\
\hline 1.Zones of very gentle chemical denudation & $\begin{array}{l}\text { tundra and woodtundra, semi-deserts of a moderate } \\
\text { chord }\end{array}$ & $<15$ \\
2. Zones minor DDS & $\begin{array}{l}\text { subtropical semi-deserts, steppe of a moderate chord } \\
\text { taiga and mixed forest, forest-steppe, subtropical }\end{array}$ & $15-35$ \\
3. Zones moderate DDS & steppes, savanna and equatorial forests & $35-55$ \\
4. Zones of heightened chemical denudation & mediterranean, deciduous and subtropical forests & $55-75$ \\
5. Zones of strong chemical denudation & tropical forests & $>75$ \\
\hline
\end{tabular}

At magnification of a fraction of easily dissoluble soils in conditions of a wet climate the tropical maxima would be even more. The similar zonal proportion is slave of communal regularity observed in a geographic shell - to allocation of heat and a moisture at move from poles to equator. From more northern to more southern latitudes, as a whole, the temperatures increase, the amount of precipitation is augmented. At heats the chemical processes of dissolution flow past more intensively, as the energy of crystal lattice increases, and, therefore, for transferring in an ionic condition of members is spent less energy and the potential of chemical denudation appears in warm southern latitudes maximal. The factor of water is an indispensable condition of weep both chemical process, and offset of a dissolved material by the rivers. On communal allocation of climatic arguments, so, and magnitude of a pool sink, considerable influencing can render a continentality of internal regions of continents, interplay of a land and sea in regions with oceanic climate, availability of orographic barriers etc. From higher latitudes to low diverse proportions between means DDS can be supervised.

The held review of datas on DDS of the mountain rivers of a world allows to draw a conclusion that the greatest magnitude DDS is supervised in mountain deciduous, subtropical, tropical and equatorial forests. The least moduluss DDS - in mountain steppes and semi-deserts of subtropical and moderate latitudes. On magnitude of moduluss DDS all reviewed altitude zones of mountains can be sectioned into groups (Table 2).

Table 2. The altitude zones groups on intensity of chemical denudation

\begin{tabular}{|c|c|c|}
\hline Groups of natural zones & Natural zones & $\begin{array}{c}\text {, } \\
t / \mathrm{km}^{2} \text { year }\end{array}$ \\
\hline 1.Zones of gentle chemical denudation & mountain semi-deserts of a subtropical zone & $15-35$ \\
\hline 2. Zones moderate DDS & mountain half-deserts of a moderate zone & $35-55$ \\
\hline 3. Zones of heightened chemical denudation DDS & $\begin{array}{l}\text { mountain steppes of moderate and subtropical zone, } \\
\text { mountain taiga and mixed forests }\end{array}$ & $55-75$ \\
\hline $\begin{array}{l}\text { 4. Zones of strong chemical denudation } \\
\text { 5. Zones very strong DDS }\end{array}$ & $\begin{array}{l}\text { mediterranean, deciduous and subtropical forests } \\
\text { tropical forests }\end{array}$ & $\begin{array}{c}75-90 \\
>90\end{array}$ \\
\hline
\end{tabular}

On an absolute value in mountains DDS it is more, than on plains. This is promoted some by the factors: higher pool sink, speckled lithologic composition of soils drained by the mountainrivers, considerable jointing, tectonic activity of mountain 
territories. As well as for the flat rivers, the maxima is supervised in a wood zone in a temperate zone and in subtropicequatorial forest zones. However oilpainting of a spatial distribution DDS in mountains more composite, than on plains. There is a maxima in subnival and glacial zones, it is possible to explain a genesis which one by a considerable water flow, greater carbonaceous capacitance of natural waters at under temperatures, considerable mechanical denudation, the magnitude by which one, definite on a drain of suspended solids, here is max among all mountain zones. The friable material, arriving at the expense of mechanical demolition, can be a padding source of solutes.

The relevant value has a geographic location of mountains, more sharp abatement of temperature with altitude. In mountains more rapid gang of mountain zones, rather than of natural zones on plains is supervised. All this constructs additionals for one more differentiated as contrasted to by plains of allocation DDS of the mountain rivers.

The spatial distribution DDS at a global level is learnt. Some locales and quadrants distinguished from each other by magnitudes DDS are chosen. The Asian region. The maximal magnitudes DDS are dated for its southeast pacific and southern indian quadrants, namely, to Southern China, Indochina, Zondes isl., Eastern India. Reasons of heightened chemical denudation - broad progressing of easily dissoluble soils and great many of precipitations. A consequent of weep of intensive chemical processes is originating karst territories. To chemical processes also favour good drain because of a raised and mountain relief, specially in headwaters. In basins of the rivers of Southern Asia a heat of air and the copious rain precipitations boost high speeds of chemical dissolution and weathering at the expense of a hyperoxemia of grounds and high contents of carbonates.

The considerable territories of Siberia of Russia, differ by low-level magnitudes of a drain of a dissolved material. The rivers here are disposed within the limits of temperate sharply of continental and subarctic climate. The dry cold climate considerably loosens processes of a chemical weathering. The availability of a permafrost in northern regions and, places, in central parts of considered territory loosens contact of melt waters in warm time with rocks. The moduluss DDS are inflected from 5-10 in northern regions of considered territory till 10-20 t/km2 year to the south.

The offset of solutes by the rivers of Northern China is rather insignificant. The basins of such rivers, as Huanche, Haihe etc., originating on a Loess plateau and in Ordos, are in subhumid and temperate subarid zones. A dry and cool climate and infrequent vegetation do not favour to weep of processes of a chemical weathering. Differs heightened DDS European region. Three sectors on magnitude DDS - northen-european, central-european and east-european are isolated. Predominantly, territory of Fennoscandia goes into a northen-european part. The magnitudes DDS here seldom exceed 10-20 t/km2 year. The climatic conditions have an effect unfavorable for weep of chemical processes. On a majority of Finland the products of breaking down of crystalline soils of the foundation of Russian gantry and fluvioglacial of deposition prevail. Only on an extreme southwest, in atlantic region of the Scandinavian mountains there are favourable lithologic, climatic and geomorphological conditions for weep of intensive processes of dissolution of soils all the year.

All rest of Foreign Europe is included in the Central European sector. Maximal magnitudes DDS here are noted. So, the moduluss DDS of the rivers originating in the Alpes, Western Caucasus, reach 250-320 t/km2 year. In less humidified and low-level Carpathians the mean indexs are a little temperated and compound 60-100 t/km2 year.

Doubtlessly, so considerable DDS promote large moistering of Western Europe, as a whole, soft temperate oceanic climate, availability of young mountains of the Alpine orogeny, widespread occurrence of easily dissoluble sedimentary stratas. Classic karst area Kras in Dinara mountains, where speeds of karst denudation of $90-100 \mathrm{mms} / 1000$ of years and more here is. The karst on Caucasus is widely advanced. The remaining territory also differs by considerable progressing of karst processes and miscellaneous shapes of a karst relief.

The East Europe sector of locale encompasses predominantly Russian plain. The territory differs by considerable dimensional variability DDS, that, doubtlessly, is conditioned by variety of geographic conditions. In many respects, the diversity in allocation DDS is connected with lithologic by the factor. The period of development carbonaceous, carbonate-sulphour and sulphour Permian soils is selected Preuralian, where DDS reaches 120-170 t/km2 year and more. Other leases of heightened values DDS (50-55 t/km2 year) are dated for exits of soils, similar on composition, in limits of the arbor. Heightened DDS it is marked in Belorussia-Baltic, Moscow-Dvinean, Timano-Pechorian region and other karst areas of Russian plain.

In the North-American locale some sectors with miscellaneous intensity DDS are selected, his(its) minimum magnitudes are dated for islands of Canadian arctic archipelago, northern part of continent - to territory dated to Hudson to embayment, down to Central plains in the south and Great plains in west. Dominating moduluss DDS less than 10 $\mathrm{t} / \mathrm{km} 2$ year. The reasons it are quite obvious - unfavorable to weep of chemical processes climatic conditions (cold, continuous winters, short warm period, small amount of precipitation), availability of a permafrost and dominance of crystalline soils of the Canadian board which has been well washed out fluvioglacial depositions.

The rather low-level chemical offset in a southwest part of continent in internal plateaus, high upland-region and 
plateaus, on a peninsula of Californium is instituted by a small amount of precipitation, small water flow. Area maximal DDS - Cordilleras, basin p. Mississipi, Central America. The greatest sink of a dissolved material is dated to western, well humidified mountain circuits (networks) Cordilleras, where on pacific coast even in winter time, due to influencing warm Alaska and Northen-Pacific currents, temperature is not lowered (sunk) below $0^{\circ} \mathrm{C}$. The moduluss DDS of the rivers of Alaska compound 40-80, in most favourable conditions reach $100 \mathrm{t} / \mathrm{km} 2$ year. The western part of Cordilleras differs by intensive tectonic moves, here, in the field of the Alpine plicated zone the modern volcanism is advanced, frequently there are earthquakes, which one result in magnification of fracturing of soils, inflow of a padding detrital material.

The mesozoic plicated area of Cordilleras is less humidified, as is in an orographic shadow in relation to Quiet ocean and is deleted from Atlantic. Maximal DDS is supervised only within the limits of Rocky mountains. Greatest DDS is supervised on leases of progressing of karstic soils in basin p. Mississipi, St. Lowrence and specially in humid tropics of Central America.

Southern America is disposed predominantly in low latitudes, differs maximal on the Earth by a pool sink. All this promotes an intensive chemical weathering in a warm wet climate. However as unfavorable for chemical denudation of the factors the gentle progressing of easily dissoluble soils and strong pan out of products of an weathering appears.

The chemical offset in basins of the mountain rivers off from slopes of Andes (rr. is most significant. Magdalena, sources of Amazon), moduluss DDS 65-150 t/km2 year. The flat rivers of basin of the Atlantic ocean differ maximal DDS in absolute expression by virtue of a huge pool sink (Amazon - 240, Parana - 40, Madeira - 32, Orinoko - 22 mln.t/years of solutes).

The Australian locale is legiblly isolated on two sectors - continental and insular. The highest moduluss of a sink are supervised in an insular part of locale, which one differs by extremely favourable conditions of weep of chemical processes - large water flow, high positive temperatures and dominance of a mountain relief. Within the limits of islands widespread of karstic rocks and applicable shapes of a relief.

The moduluss DDS on large islands of Oceania in some times higher(some times above) moduluss of a sink of the continental rivers also reach 50-150, maximum rating - $247 \mathrm{t} / \mathrm{km} 2$ year - for $p$. Fly. Within the limits of the most Australian continent DDS is insignificant. Basic DDS is carried out a fluvial system Murray-Darling, disposed predominantly in a zone of dry steppes, subtropical semi-deserts, and does not exceed $5 \mathrm{t} / \mathrm{km} 2$ year. The majority of continent is occupied by tropical and subtropical deserts, where the limiting factor for weep of chemical processes, as, however, and for all continent is the small of a pool sink.

And only in extreme east of continent, in limits of well humidified western slopes ancient and broken down during long-lived geologic time Large watershed ranges moduluss of a sink are increased up to $20 \mathrm{a}$ little $\mathrm{t} / \mathrm{km} 2$ year, and the places, in favourable lithologic-and-petrographic conditions, where datas advance a karst in paleozoic calcareous stratas, - up to $30 \mathrm{t} / \mathrm{km} 2$ year.

The African continent differs by the least moduluss DDS. Argument to this in broad progressing of arid and sevenarid landscapes, predominantly in flat nature of a relief, propagation of powerful crusts of an weathering and infrequent exits of easily dissoluble soils.

The considerable magnitudes DDS are supervised only in one area of Africa - in the Mediterranean Atlas. DDS of the largest rivers of this area reaches $90-180 \mathrm{t} / \mathrm{km} 2$ year. Only in this locale of Africa most widely karst also is is full advanced, which one is dated for mountains and piedmonts referring to fissile in tectonic a ratio to the Alpine plicated zone.

The denudational part in communal fluvial DDS is counted. The offset of salts conditioned by processes of an weathering, is counted on a differential between communal fluvial DDS and sum of matters of an atmospheric genesis, and also anthropogenous genesis. On the average, is accepted, that 50,8\% from a communal sink of hydrocarbonateions is compounded by(with) their denudational part. With allowance for it, the sink denudational component of a sink of hydrocarbonate-ions is valued in $865 \mathrm{mln}$.t. After count on hydrocarbonate-ions, the fraction of all ions having denudational genesis, from communal fluvial DDS will make $56 \%$. Allowing obtained magnitude, the mean modulus of chemical denudation will make $16,9 \mathrm{t} / \mathrm{km} 2$ year.

The determination of magnitude of chemical denudation grounded by a method of the account of loss of a weight of standard samples of rocks (method of tablets) on results of stationary overseeings by intensity of chemical denudation on territory Mean Volga river region and Kola peninsula for a period with 1988 on 1999 years.

The tablets of miscellaneous lithologic composition (gypsum, anhydrite, chalkstone) were gobed up in miscellaneous landscape conditions from tundra up to forest-steppes on different ground features - watershed, slope etc.

The intensity of chemical denudation is instituted by magnitude of loss of a weight of tablets, which one are recounted in values of a decrease of a surface of tablets and are expressed per one $\mathrm{mm} /$ year. The minimum, maximal and mean values for tablets of miscellaneous lithologic composition and separately on ground features (watershed, slope) 
were counted.

The mean values of chemical denudation, definite method of tablets, demonstrate, that among all tablets anhydrite, specially in a southern taiga, and more slowly all - chalkstone is diluted fan-in harder. The losses of a weight of anhydrite compound 0,7 mm/years in forest-steppes; 1,99 -в to a southern taiga; 3,22 - in northern taiga and 3,1 - in tundra. For chalkstone the denudational decrease compounds 0,58 - in a southern taiga; 0,78 - in tundra, and in forest-steppes and in northern taiga on some tablets even minor increment of a weight is supervised per separate years. For gypsum the magnitude of denudation has compounded: $0,27 \mathrm{~mm} /$ years in forest-steppes; 0,97 - in to a southern taiga.

\section{Conclusions}

Thus, the definite regularity is supervised: with magnification of locale, and in given we happen it of a part of a light or continents, the diversity of dimensional differentiation DDS is augmented, that is conditioned by the greater continentality of large locales, interplay of a land and sea. As a whole, in central parts of continents the sink dissolved is less, it increases to their western and eastern to peripherals. The area with maximal magnitudes DDS are high Alpine mountainplicated areas of locales.

\section{References}

Corbel J., 1959. Erosion en terrain calcaire: vitesse d'erosion morfologie // Ann. geogr., V. 68 (366), pp. 124-130.

Corbel J., 1964. L'erosion terrestre, etude quantitative (Methodes. Techniques. Resultats) // Ann. geogr., V. 73 (398), pp. 385-412.

Dedkov A.P., V.I. Moszerin, A.N. Sharifullin and R.R. Denmukhametov, 2005. Recent denudation of the Earth's plains according to data on sediment and dissolved substance load. Isvestiya Akademii Nauk, Seriya Geograficheskaya, 5: pp. 30-38.

Hren M.T., C.P. Chamberlain, G.E. Hilley, P.M. Blisniuk, B. Bookhagen, 2007. Major ion chemistry of the Yarlung Tsangpo-Brahmaputra river: Chemical weathering, erosion, and $\mathrm{CO}_{2}$ consumption in the southern Tibetan plateau and eastern syntaxis of the Himalaya// Geochimica et Cosmochimica Acta, 71, pp. 2907-2935.

Jakucs L., 1970 The role of climate in the quantitative and qualitative control of Karstic corrosion // Acta geogr., Szeged, V.10 (1-8), pp. 3-19.

Urazmetov, I.A., Smirnova, E.V. (2014). Ecological state of water and soil of natural-anthropogenic landscapes in the oil-producing regions. Mediterranean Journal of Social Sciences, 5 (18 SPEC. ISSUE), pp. 367-372

Meybeck, M., 2003. Global analysis of river systems: from earth system controls to Anthropocene controls // Philos. Trans. Roy. Acad. Lond., B 358, pp.1935-1955.

Gaisin, I.T., Beketova, S.I., Gaisin, R.I. Competence-based approach as an effective way to increase the level of training of geographers in universities // Life Science Journal 2014;11(11 s)C.166-170.http//www.lifesciencesite.com

Mudd S.M., 2004. Influence of chemical denudation on hillslope morphology //Journal of geophysical research, vol. 109, pp. 1-17. DOI:10.1029/2003JF000087.

Biktimirov, N.M., Gaisin, R.I., Gaisin, I.T. The use of new methodologies for demographic investigations in national-territorial subdivisions of Russia. Life Science Journal, 11 (SPEC. ISSUE 8), pp. 194-197.

Kinossian, N. (2012). 'Urban entrepreneurialism' in the Post-socialist City: Government-led Urban Development Projects in Kazan, Russia. International Planning Studies, 17 (4), pp. 333-352.

Pulina M., 1974. Denudacja chemisna na obszerach krasu weglawege // Pr. Geogr. Inst. Geogr. PAN, 105., 159 p.

Xiang H., M. Sillanpää a, T. E. Gjessing, D.V. Rolf, 2009. Water quality in the Tibetan Plateau: Major ions and trace elements in the headwaters of four major Asian rivers // Science of the Total Environment, 407, pp. 6242-6254.

Zhang, S.-R., X. X. Lu, D. L. Higgitt, C.-T. A. Chen, H.-G. Sun, and J.-T. Han, 2007. Water chemistry of the Zhujiang (Pearl River): Natural processes and anthropogenic influences // Journal of geophysical research, vol. 112, pp. 1-17.

Zhang, L.T., 2000. Analysis of portion of the ternary diagram for major ions in river water of Pearl River system // Acta Sci. Natural., 39, pp.102-105.

Smirnova, E.V., Urazmetov, I.A. (2014). Specifics of land cover of natural anthropogenic landscapes in oil production regions. International Multidisciplinary Scientific GeoConference Surveying Geology and Mining Ecology Management, SGEM, 1, pp. 765770. 